\title{
Contribution of insect pollinators to crop yield and quality varies with agricultural intensification
}

Background. Up to $75 \%$ of crop species benefit at least to some degree from animal pollination for fruit or seed set and yield. However, basic information on the level of pollinator dependence and pollinator contribution to yield is lacking for many crops. Even less is known about how insect pollination affects crop quality. Given that habitat loss and agricultural intensification are known to decrease pollinator richness and abundance, there is a need to assess the consequences for different components of crop production. Methods. We used pollination exclusion on flowers or inflorescences on a whole plant basis to assess the contribution of insect pollination to crop yield and quality in four flowering crops (spring oilseed rape, field bean, strawberry, and buckwheat) located in four regions of Europe. For each crop, we recorded abundance and species richness of flower visiting insects in ten fields located along a gradient from simple to heterogeneous landscapes. Results. Insect pollination enhanced average crop yield between 18 and $71 \%$ depending on the crop. Yield quality was also enhanced in most crops. For instance, oilseed rape had higher oil and lower chlorophyll contents when adequately pollinated, the proportion of empty seeds decreased in buckwheat, and strawberries' commercial grade improved; however, we did not find higher nitrogen content in open pollinated field beans. Complex landscapes had a higher overall species richness of wild pollinators across crops, but visitation rates were only higher in complex landscapes for some crops. On the contrary, the overall yield was consistently enhanced by higher visitation rates, but not by higher pollinator richness. Discussion. For the four crops in this study, there is clear benefit delivered by pollinators on yield quantity and/or quality, but it is not maximized under current agricultural intensification. Honeybees, the most abundant pollinator, might partially compensate the loss of wild pollinators in some areas, but our results suggest the need of landscape-scale actions to enhance wild pollinator populations. 


\section{Authors:}

2 Ignasi Bartomeus ${ }^{a, 1}$, Simon G. Potts ${ }^{b}$, Ingolf Steffan-Dewenter ${ }^{c}$, Bernard E. Vaissière ${ }^{d}$,

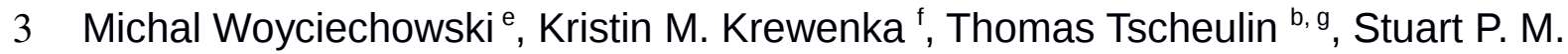

4 Roberts $^{\mathrm{b}}$, Hajnalka Szentgyörgyi ${ }^{\mathrm{e}}$, Catrin Westphal ${ }^{\mathrm{f}}$, Riccardo Bommarco ${ }^{\mathrm{a}}$.

\section{Affiliations:}

6 a Swedish University of Agricultural Sciences, Department of Ecology, Uppsala, Sweden.

7 b University of Reading, School of Agriculture, Policy and Development, Reading, RG6

$86 \mathrm{AR}, \mathrm{UK}$

9 c University of Würzburg, Department of Animal Ecology and Tropical Biology, Biocentre,

1097074 Würzburg, Germany

11 d INRA, UR406 Abeilles \& Environnement, 84914 Avignon, France

12 e Jagiellonian University, Institute of Environmental Sciences, Gronostajowa 7, 30-387

13 Krakow, Poland.

14 ' Georg-August-University, Department of Crop Science, Agroecology, Grisebachstr. 6,

1537077 Göttingen, Germany

$16{ }^{g}$ University of the Aegean, Department of Geography, 81100 Mytilene, Greece

17 1Corresponding author: Ignasi Bartomeus; nacho.bartomeus@gmail.com; @ibartomeus 
Introduction

19 There is growing evidence that ecosystem services, such as biological pest control and

20 crop pollination, benefit food production (Bommarco et al. 2013). Indeed, $75 \%$ of the

21 crop species used for food depend on insect pollination to some degree (Klein et al.

22 2007). More than a decade of active pollination research has led to a greatly improved

23 general understanding on animal pollination benefits to crop yields worldwide (e.g., Klein

24 et al. 2007; Garibaldi et al 2011, 2013). However, major knowledge gaps remain.

25 First, we have surprisingly little information on the actual degree of pollinator

26 dependence for some major crops. While some crops depend entirely on insect

27 pollinator visits to set fruit, many others are only partly dependent on animal pollination

28 and can produce more than $90 \%$ of the maximum seed or fruit yield without pollinators

29 (Klein et al. 2007). The role of pollinators for crop production has mainly been examined

30 in observational studies, relying primarily on natural variation in visitation rates among

31 observed sites. Experiments directly manipulating insect flower visitation (e.g., excluded

32 pollinators vs. open access of pollinators) are less common for most crops (but see

33 Klein et al. 2003, Höhn et al. 2008). Assessing pollination dependence with proper

34 controls is needed to correctly estimate the contribution that insect pollinators can

35 provide to crop yields.

36 Second, most available studies quantify the number of fruits per plant. Fruit number can

37 be a good proxy for yield (Garibaldi et al. 2013), which is the amount of produce

38 harvested per unit area. However, the correlation between the number of fruit produced

39 and yield may be low in some crops. For example, interspecific plant competition can

40 lead to high variability in plant size and thereby fruit production among plants. This is 
especially critical for crops with indeterminate flowering and a high compensation

42 capacity such as soybean (Glycine max) and oilseed rape (Brassica napus). For these,

43 fruit set measured on a limited number of isolated plants is unlikely to be representative

44 of the real production in a crop stand (Stivers \& Swearingin 1980, Angadi et al. 2003).

45 Moreover, plants can allocate resources for producing fruits of variable size based on

46 the number of fruits per plant and the level of pollination received (e.g., Gonzalez et al.

471998 in kiwifruit Actinidia deliciosa), such that similar levels of fruit set can differ in total

48 crop yield because of difference in fruit size (Bos et al. 2007). Again, the use of proper

49 control plants from which pollinators are excluded is a way to better estimate the actual

50 contribution of pollinators to yield in such crops.

51 Quality is also important in crop production, especially from an economic standpoint.

52 Fruit quality can be negatively correlated with quantity when the fruit load on a tree or a

53 vine is too high (e.g., Ferguson \& Watkins 1992 in apple Malus $x$ domestica), but it is not

54 so otherwise, especially in crops with indeterminate flowering such as oilseed rape

55 (Bommarco et al. 2012). Indeed, adequate pollination often leads to produce with

56 enhanced quality in entomophilous crops such as orchard fruit production (e.g., in apple

57 - Sheffield et al. 2005, Garratt et al. 2014), as well as in field crops (oilseed rape -

58 Bommarco et al. 2012) and small fruits and vegetables (e.g., strawberry Fragaria $x$

59 ananassa - Andersson et al. 2012, Chagnon et al. 1993, Roselino et al. 2009; tomato

60 Solanum lycopersicum - Hogendoorn et al. 2010; bell peppers Capsicum annuum -

61 Roldan Serrano and Guerra-Sanz 2006 ; highbush blueberry Vaccinium corymbosum -

62 Isaacs and Kirk 2010).

63 Given the drastic shifts in community composition of insects that visit flowering crops 
64 (Winfree et al. 2011, Bommarco et al. 2011, Bartomeus et al. 2013a), and declines in

65 numbers of pollinator species observed in some regions (Potts et al. 2010, Carvalheiro

66 et al. 2013), it is increasingly important to gather information on the extent to which

67 different crops depend on insect pollination for yield, and if current pollinator

68 communities fulfill the demand for pollination services such that both crop quality and

69 yields are maximized (Breeze et al. 2011). Relationships between land use intensity,

70 pollinator visitation, and fruit set have been well studied. While pollinator species

71 richness consistently and drastically decays as agricultural landscapes are deprived of

72 natural habitat and are more intensively cultivated (Kennedy et al. 2013), this

73 relationship is much weaker for fruit set (Garibaldi et al. 2011, Chacoff et al. 2008,

74 Ricketts et al. 2008). One explanation for this difference is that the remaining pollinators

75 provide sufficient visitation even in homogenous, intensively cultivated landscapes,

76 especially if the crop has a large degree of autonomous self-pollination. Moreover,

77 intensive landscapes are characterized by harboring just a few generalist pollinator

78 species (Bartomeus \& Winfree 2013), but these might be in sufficient numbers to deliver

79 enough crop pollination services. In fact, not all pollinator species respond equally to

80 land use change (Williams et al. 2010, Winfree et al. 2011), and some even increase in

81 abundance with agricultural intensification (Westphal et al 2003, Carré et al. 2009). This

82 diversity of pollinator responses can, in some cropping systems, buffer a loss of

83 pollination functioning (Cariveau et al. 2013); especially so if the pollinators who are the

84 main ecosystem service providers are adapted to the ephemeral and patchy resource

85 distribution that is typical for agricultural landscapes. Moreover, although wild insects

86 increase fruit set independently of honeybee visits (Garibaldi et al. 2013), honeybees

87 are less dependent on landscape characteristics because they are mainly managed,

88 particularly in North America and Europe, and can be moved around in the landscape. 
Hence, honeybees can also help mitigate against wild pollinator loss in more intensively used landscapes where pollination services are degraded. In any case, the composition

91 of the landscape in which the flowering crop field is embedded emerges as an important

92 driver for pollinator community composition, and the landscape context needs to be

93 considered when linking land use to pollination provisioning and benefits in field crops.

94 Here we used pollinator exclusion on the flowers or inflorescence on a whole plant basis

95 in a set of crops under standard field conditions, to quantify pollinator dependency for

96 four economically important annual crops in Europe. We assessed pollinator contribution

97 to both yield quantity and quality. By replicating this experiment along a landscape

98 gradient for each crop, we were able to test the hypothesis that pollinator visitation rate

99 decrease with agricultural intensification and its consequences for crop pollination

100 services and production.

\section{$101 \quad$ Material and Methods}

\section{Study sites}

103 The fieldwork was conducted in four European countries during May-August 2005

104 (Table 1). Spring oilseed rape (Brassica napus) was assessed in the region around the 105 city of Uppsala, Sweden (see Bommarco et al. 2012 for details); field bean (Vicia faba)

106 in around Reading, UK, strawberry (Fragaria x ananassa) around Göttingen, Germany;

107 and buckwheat (Fagopyrum esculentum) near Krakow, Poland. For each crop, we

108 selected ten fields that were separated by a minimum distance of $3 \mathrm{~km}$, corresponding

109 to the maximum foraging range of most bees (Greenleaf et al. 2007). Within each field, 110 we established a 50 * $25 \mathrm{~m}$ study area (5*150 m for buckwheat as the fields were long 
111 and narrow) with a homogeneous and continuous crop cover. For fields up to two ha in

112 size, this study site was located in the middle of the field. For larger fields, it was located

113 between the geometric center of the field and one of its margins (Vaissière et al. 2011).

\section{Insect sampling}

115 In each field, we assessed the abundance and species richness of the major groups of

116 flower-visiting insects, including bees (Hymenoptera: Apoidea: Apiformes), hoverflies

117 (Diptera: Syrphidae), and butterflies (Lepidoptera). We used standardized transect walks

118 with an aerial net (Westphal et al. 2008). In each study site, a $150 \mathrm{~m}$ transect line was

119 established in the field near the experimental plots. An observer walked this line for 30

120 min identifying visiting insects at species level and catching unidentified species within a

121 corridor $4 \mathrm{~m}$ wide. We performed the transect walks between 0900 and 1700 hours only

122 on days with temperatures at or above $15^{\circ} \mathrm{C}$, with no precipitation, dry vegetation, and

123 low windspeed (<40 km.h ${ }^{-1}$; Westphal et al. 2008). Specimens were pinned, labeled, and

124 subsequently identified to species level. We returned four times to each study site during

125 the main flowering period of each study crop.

\section{Experimental design and yield analysis}

127 In each of the ten fields, we established a block experiment with four blocks (Fig 1).

128 Each block had two treatments with one plot per treatment and five to ten tagged

129 contiguous plants monitored per plot. The first treatment (Open) was open pollinated

130 with all the flowers of each plant accessible to autonomous self-, wind- and insect-

131 pollination. In the second treatment (Net), all flowers were enclosed in nylon tulle bags

132 with 1 * $1 \mathrm{~mm}$ openings (Diatex F510; http://www.diatex.fr/-Agriculture-.html) of an

133 appropriate size to cover an inflorescence (buckwheat, field bean \& oilseed rape), or an 
134 individual flower (strawberry). Thus, in the Net-treatment all flowers were exposed to

135 wind- and self-pollination, but not to insect pollination. Because such nets do not hinder

136 the airborne pollen flow (Sacchi and Price 1988, Wragg and Johnson 2011), the

137 difference between these treatments represents the contribution from insect pollination.

138 Bag manipulations were done carefully and in most cases before or after anthesis to

139 avoid increased levels of self-pollination. We put the nets over the flower buds before

140 the onset of flowering. Leaves and plant parts with no flowers were left as much as

141 possible outside the net bag to minimize any effects of the bag on the photosynthesis

142 (Howpage et al. 2001). As soon as flowers had wilted, we removed the nets, and the

143 tagged plants were left to ripen in the field until harvest.

144 For buckwheat, field bean, and oilseed rape, we cut all experimental plants from each

145 plot and stored them individually in a linen bag just before commercial harvest. For

146 strawberry, we followed the commercial harvest procedure and harvested the ripe

147 strawberries twice a week. In each plot, we recorded fruit set as the number of fruits per

148 plant (field bean, oilseed rape, and strawberry) or seed set as the number of seeds per

149 plant (buckwheat). Yield was measured as the total weight of seeds per plant

150 (buckwheat, field bean, and oilseed rape) or total fresh weight (strawberries) measured

151 using a precision scale. As plants grew in field conditions with typical densities, the

152 mean production per plant is a good proxy of tones per hectare obtained by the farmer.

153 For each crop, we also measured the specific attributes of quality that affect its

154 marketing value. For oilseed rape, we analyzed the oil content and chlorophyll contents

155 of the seeds (performed by Svalof Weibull Lab AB, Svalov, Sweden). High chlorophyll

156 contents decrease the durability and alter the color of the extracted oil. For field beans,

157 we measured the nitrogen content of the seed as a proxy of their protein content. The 
158 nitrogen content was measured using oxidative combustion in an automated Dumas

159 type combustion analyzer. For strawberry, we classified commercial quality as grade 1

160 (fully developed fruits of good quality), grade 2 (marketable fruits with some changes in

161 colour and shape) and grade 3 (non-marketable fruits) according to guidelines of the

162 German board of trade. For buckwheat, we measured the proportion of filled seeds

163 since high proportion of empty seeds leads to a penalty in the market price. For

164 buckwheat, six fields where destroyed due to a hailstorm, and hence we do not have 165 yield measures for those.

\section{Landscape context}

167 The ten fields for each crop were located along a gradient of surrounding landscape

168 complexity. The gradient ranged from intensive agricultural landscapes dominated by

169 large arable fields with few boundary features, to complex landscapes with smaller

170 average arable field sizes and more than 40\% coverage of semi-natural habitats, such

171 as pastures and forest patches over $0.5,1,2$, and $3 \mathrm{~km}$ radius around each study field.

172 When selecting the field sites, the proportion of arable land in the surrounding landscape

173 was measured around each experimental field and used as a proxy for landscape

174 complexity (Steffan-Dewenter et al. 2002, Fahrig 2013). The proportion of arable land in

175 the landscape surrounding each of the ten experimental fields varied depending on the

176 region, with some regions presenting more intense landscapes (e.g., range of 48 to 97

$177 \%$ of agricultural land for oilseed rape fields at $1000 \mathrm{~m}$ radius), and other regions

178 presenting more complex landscapes (range of 4 to $45 \%$ of agricultural land for field

179 bean at $1000 \mathrm{~m}$ radius; Table 1$)$.

180 For oilseed rape, we used the Swedish digitized land cover terrain map database to 
181 characterize the landscape surrounding each field (Lantmateriet 2008). For buckwheat

182 and strawberry, we used CORINE data from 2006 (European Environment Agency:

183 http://www.eea.europa.eu/data-and-maps/data/corine-land-cover-2006-raster-2). For

184 field beans we used the CORINE 2000 Land Cover Map

185 (http://www.ceh.ac.uk/landcovermap2000.html).

186 Data analysis and statistics

Landscape effects on bee richness and visitation

Because different organisms act in and react to the landscape at different spatial scales,

189 it is necessary to find a suitable scale at which to measure the surrounding landscape

190 (Steffan-Dewenter et al. 2002; Henry et al. 2012). Before exploring any significances, we

191 ran models for each variable with each of the different radii $(0.5-3 \mathrm{~km})$ at which the

192 landscapes had been measured. Hence, for each crop we regressed percentage of

193 agricultural area against pollinator richness and abundance at different radii, and

194 identified the radius that explained the highest proportion of variance (highest $\mathrm{R}^{2}$ ). For

195 species richness, all crops showed the highest $R^{2}$ at a radius of $0.5 \mathrm{~km}$, while

196 abundance was best explained at a $1 \mathrm{~km}$ radius with the exception of field bean bee

197 communities, which also responded to a larger scale (1500 m). We performed joint

198 models for all crops at 0.5 and $1 \mathrm{~km}$ radius for richness and visitation abundance,

199 respectively. Bee species richness showed a similar relation to landscape complexity for

200 all crops, and this permitted us to include 'crop' as random factor in the model to

201 investigate the general influence of landscape on richness. Visitation abundance,

202 however, followed contrasting trajectories in relation to landscape depending on the

203 crop. We therefore included in the model crop and its interaction with landscape as fixed 
204 effects. Pollinator abundances were centered and scaled to a mean of zero and a

205 deviation of one within each crop. Visual inspection of rarefaction curves showed that we 206 did not capture all species richness in most sites, therefore richness values should be

207 interpreted as relative richness detected with an equal sampling effort. However, as real

208 richness can be easier to detect in sites with higher pollinator abundance, we also ran

209 the richness model for rarefied species richness at the minimum sampling size levels for

210 each crop (Gotelli and Colwell 2001).

\section{Yield quantity and quality}

212 We first correlated fruit set (or seed set for buckwheat) with yield for each crop. While we

213 expect both to be correlated (i.e., plants with more fruits or seeds, should also have

214 higher yield), this correlation can be stronger or weaker depending on the crop studied.

215 Block was nested within site and included as random factor in all models. Second, we

216 constructed one mixed effect model with yield as the response variable. In order to

217 analyze all crops in the same model, yield and pollinator visitation abundance were

218 centered and scaled to a mean of zero and a deviation of one within each crop. We used

219 pollination treatment, species richness, total visitation abundance, landscape and the

220 interactions of treatment with the other three variables as predictors. Landscape was

221 investigated at 0.5 and $1 \mathrm{~km}$ radius with similar results and so only models at $1 \mathrm{~km}$ are

222 shown. Block, nested within site, nested within crop was included as a random factor in

223 all models. We checked that different crops do not present different responses by

224 comparing AICc of this model to a model incorporating total visitation as a random slope.

225 A significant interaction with treatment would indicate that the factor had an effect on

226 yield only in the open treatment. To account for heteroscedasticity, we added a constant 
227 variance structure (varldent function in package nlme, $\mathrm{R}$ ) in which the variance was

228 independently specified for each crop (Cleasby et al. 2011).

229 We also checked if yield and quality were affected by the pollination treatment for each

230 crop. Each crop was analyzed independently due to different quality measurement units

231 and also because there was no homogeneous response among the crops. Block nested

232 within site was included as a random factor in all models. In this case, we tested only for

233 the effect of the pollination treatment, without including the interactions with species

234 richness, visitation abundance, or landscape context due to sample size limitations. For

235 buckwheat, we used block as a constant variance function to control for the different

236 heteroscedasticity among blocks. The package $n / m e$ in $\mathrm{R}$ was used to fit all models

237 (Pinheiro et al. 2013). Residual plots where used to check for normality and

238 standardized residuals for heteroscedasticity.

\section{Results}

240 Landscape effects on bee richness and visitation

241 Pollinator species richness ranged from 2 to 26 species per site (Table 1 ). The flower

242 visitors of all crops were highly dominated by one or two species of pollinators, in most

243 cases managed honeybees. In field beans, the dominant species were bumblebees;

244 Bombus terrestris/lucorum complex, followed by B. hortorum and B. lapidarius (Fig. 2).

245 Simple landscapes had consistently lower species richness in all crops (GLMM: $F_{1,35}=$

$2465.39, P=0.02$; Fig. $3 A$ ). All crops responded similarly (slope $\pm S E=-8.43 \pm 3.63$ ), but

247 with different intercepts $($ Field bean $=-8.39$; Buckwheat $=1.90$; Oilseed rape $=3.14$;

248 Strawberry $=3.35)$.

249 This trend is consistent when using rarefied species richness (GLMM: $F_{1,35}=3.66, P=$ 
0.06). However, the pollinator abundance trend depended on the crop (Table 2; Fig. 3B).

251 Visitation patterns were driven by the visitation of a single species, the managed

252 honeybee, in all crops except for field beans (Table 2). While in most regions honeybee

253 visits were also higher in complex landscapes, in buckwheat there were higher

254 honeybee visits in simple landscapes. For field beans, this positive relationship between

255 number of visits recorded and landscape was even more pronounced at larger scales

256 when we analyze the primary pollinators, the bumblebees, alone $\left(F_{1,8}=6.44, P=0.03\right.$ at

$2571.5 \mathrm{~km}$ radius). Honeybee visits is not strongly correlated with overall non-honeybee

258 visits (Field bean Pearson $r=0.19$; Buckwheat $=0.47$; Oilseed rape $=0.51$; Strawberry

$259=0.32$ ), and we do not detect an effect of landscape on overall non-honeybee visitation

260 (Table 2).

261 Yield quantity and quality

262 Fruit or seed number per plant were in all cases positively correlated with yield

263 (measured as weight per plant). However, the correlation was stronger in some crops

264 than others (oilseed rape: $R^{2}=0.95, P<0.0001$; field bean: $R^{2}=0.90, P<0.0001$;

265 strawberry: $R^{2}=0.61, P<0.0001$; buckwheat: $\left.R^{2}=0.67, P<0.0001\right)$.

266 Open pollination increased yield for all crops (Field bean estimate $=16.42 \pm 3.30$

$267 \mathrm{~g} /$ plant, $\mathrm{df}=67, \mathrm{t}=4.97 \mathrm{P}=0.03$; Buckwheat estimate $=42.44 \pm 8.27 \mathrm{~g} /$ plant, $\mathrm{df}=24$,

$268 \mathrm{t}=5.12 \mathrm{P}<0.001 ;$ Oilseed rape estimate $=0.87 \pm 0.38 \mathrm{~g} /$ plant, $\mathrm{df}=69, \mathrm{t}=2.22 \mathrm{P}=$

269 0.03; Strawberry estimate $=2.16 \pm 0.41 \mathrm{~g} /$ plant, $\mathrm{df}=67, \mathrm{t}=5.30 \mathrm{P}<0.001 ;$ Fig. 4).

270 When analyzing all crops in combination, we did not detect an interaction between

271 treatment and species richness, which indicates that higher richness does not increase

272 yield in any of the treatments. However, total visitation rate increased yield in both 
273 treatments (Fig 5A) and the response was consistent among crops as indicated by the

274 fact that allowing the variation in the slope of each crops do not improve the model

275 ( $\triangle$ AICc between competing models $=15)$. Interestingly, landscape complexity measured

276 as \% of agricultural land (both at 0.5 or at $1 \mathrm{~km}$ ) also showed a significant interaction

277 with treatment, indicating that simpler landscapes had lower yields in the open pollinated

278 plants. However, the trend for net-bagged plants was reversed (Table 3; Fig. 5B).

279 In addition to quantity, the quality of oilseed rape, buckwheat and strawberry increased

280 in the open pollination treatments (oilseed rape: oil content estimate $=1.28 \pm 0.31 \%$, df

$281=39, \mathrm{t}=4.18 \mathrm{P}<0.001 ;$ Chlorophyll content estimate $=-4.15 \pm 1.76 \mathrm{ppm}, \mathrm{df}=39, \mathrm{t}=$

$282-2.37, P=0.02$; buckwheat: percentage of filled seeds estimate $=0.08 \pm 0.01 \%, \mathrm{df}=12$,

$283 \mathrm{t}=6.35, \mathrm{p}<0.001 ;$ strawberry: commercial grade estimate $=-0.32 \pm 0.06, \mathrm{df}=67, \mathrm{t}=$

$284-5.36, p<0.001)$. On the other hand, the nitrogen content of field beans did not increase

285 on open-pollinated plants (estimate $=-0.10 \pm 0.08 \%, \mathrm{df}=37, \mathrm{t}=-1.16, \mathrm{p}=0.25$; Fig 4).

\section{Discussion}

287 Four economically important entomophilous annual crops in Europe demonstrated

288 highly different degrees of insect pollination dependence. When open pollinated, mean

289 yield increases ranged from 18 to $71 \%$ depending on the crop. Three of these crops are

290 listed as having a "modest" positive impact by animal pollination in the comprehensive

291 review by Klein et al. (2007). However, despite being in the same category, oilseed rape

292 and strawberry increased around $20 \%$, while field bean reached a $40 \%$ increase in

293 yield from average levels of insect pollination. The fourth crop, buckwheat is listed as

294 having a large positive impact by animal pollination, in line of our reported $71 \%$

295 increase. The review by Klein et al. (2007) is currently the best available, most up to 
date source of animal pollination dependence on crops, but our data highlight a disparity

297 of results among crops listed under the same category. Our quantitative data on animal

298 pollination dependence provides a first step to depart from the uncertainty embedded in

299 a categorical approach. For example, dependence on animal pollination can change by

300 variety and region. Recent reports show variability in pollinator dependence between 0

301 to $30 \%$ among varieties of oilseed rape (Stanley et al. 2013, Garratt et al. 2013). While

302 we were able to standardize variety for most studied crops, strawberry fields were

303 planted with four different varieties and the presented data should be seen as an

304 average across those varieties (but see Klatt et al. 2013).

305 As expected, we found that fruit or seed number per plant was positively correlated with 306 yield measured as weight of the marketable product per plant. However, this correlation

307 was rather weak $\left(r^{2} \sim 0.60\right)$ for both strawberry and buckwheat. This indicates that for

308 these crops, the total fruit or seed weight was quite variable among plants with similar

309 fruit or seed numbers. Indeed, for strawberry, the size of the receptacle is directly related

310 to the number of fertilized achenes, while for buckwheat the proportion of filled seeds

311 can vary considerably and is a major component of yield besides fruit set. While

312 previous research has focused mainly on exploring the effects of pollinators on fruit or

313 seed set (e.g., Garibaldi et al. 2011, 2013), which is a more direct measure of plant

314 reproduction, yield has the potential to better reflect economic value (Bommarco et al.

315 2012, Klatt et al. 2013), and hence, farmers' interest. For example, while less than 20\%

316 in mean yield increase may seem as a modest advantage from the plant perspective, for

317 the farmers it can translate into a substantial difference in revenue.

318 Similarly, we report that the yield quality component is enhanced to different extents by 
open pollination in three out of four crops. For buckwheat, strawberry, and oilseed rape,

320 quality is directly linked to the pollinating activity of insects. We find this despite the fact

321 that the measure of quality and underlying mechanisms are specific for each crop, and

322 largely unrelated among crops. Empty seeds in buckwheat accumulate little or no starch

323 (Björkman 1995). The shape of strawberries is directly related to a complete pollination

324 of all ovules, resulting in a homogeneously pollinated fruit (Zebrowska 1998). For

325 oilseed rape, the plant allocate more oil resources to well pollinated seeds. In contrast,

326 for field beans, the nitrogen content in the seeds was not affected by insect pollination.

327 Other factors such as soil fertility and availability of the appropriate N-fixing bacteria

328 (Rhizobium spp.) may play a more important role for field beans (Köpke and Nemecek

329 2010). However, note that we detected no trade-off between yield and nitrogen content

330 of the seeds, as plants with more seeds did not have lower nitrogen content. Hence, the

331 overall protein yield (i.e., nitrogen content at the plant level) was increased with open

332 pollination.

333 The treatment with netted flowers gives us estimates for the extreme cases where

334 pollinators are completely absent, and we show that the current levels of pollination are

335 insufficient to increase yield in the open pollinated treatment in all landscapes. As

336 previously reported, we confirm that agricultural intensification has a drastic effect on

337 bee species richness (Ricketts et al. 2008, Garibaldi et al. 2011). However, total

338 visitation does not always follow the same pattern as richness. This is the case for

339 buckwheat and field bean, where fields presenting higher total visits were located in

340 simple landscapes. For buckwheat, most of the visits in complex landscapes were due

341 to increased honeybee densities managed for pollination. Unfortunatelly, there is no

342 detailed information on where hives were placed in the landscape by local beekeepers 
343 as the hives were primarily put out for honey production, rather than pollination services.

344 In field beans we found that bumblebees responded positively to agricultural

345 simplification, noting, however, that even the more simple field beans landscapes

346 contain a fair amount of semi-natural habitats. Overall, we found a general positive

347 relationship between total visitation rates and yield, but not with species richness. If the

348 remaining species that thrive in intensively cultivated agricultural areas, including the

349 managed honeybee, are effective pollinators, yield losses can be partly decoupled from

350 losses of species (Bartomeus and Winfree 2013). However, our approach does not allow

351 us to test if current pollinator levels reach the maximum achievable yield under optimal

352 pollination conditions.

353 A recent global meta-analysis highlights the role of wild species in crop systems

354 (Garibaldi et al. 2013). The flower visitors of three out of four crops were clearly

355 dominated by honeybees (Fig. 2) and hence, are likely to be key pollinators for those

356 crops. Garibaldi et al. (2013) show that an increase in wild insect visitation enhanced

357 fruit set by twice as much as an equivalent increase in honeybee visitation. While this is

358 generally the case in our target crops (three of which were included as part of Garibaldi's

359 synthesis), the numerical advantage of honeybees in European agricultural landscapes

360 needs to be acknowledged when calculating their total contribution to pollinated plants

361 (e.g., as done in Winfree et al. 2007 and Rader et al. 2009). However, increasing or

362 maintaining high pollinator diversity can enhance yield quantity and stability by

363 improving the pollination efficiency of honeybees (Greenleaf \& Kremen 2006) and

364 reduce the risk of pollination failure due to climate change (Rader et al. 2013,

365 Bartomeus et al. 2013b), or environmental disturbances such as extreme weather

366 events (Brittain et al. 2012). 
367 Overall, we also found a weak negative effect of land use intensity on yield (Garibaldi et

368 al. 2011, but see Ricketts et al. 2008), but this was not directly mediated by increased

369 pollinator visitation by itself, because the correlation between pollinator total visits and

370 the proportion of agricultural land in the landscape was weak. The yield of experimental

371 plots with net bagged flowers also increased in sites with more pollinators (Fig 5A). This

372 suggests that other environmental or biotic factors correlated with insect visitation may

373 have been operating simultaneously. The release of airborne pollen by foraging bees

374 could be such a factor (Pierre et al. 2009).

375 In order to make efficient management decisions and increase our power to predict the

376 actual benefit from pollinators in a certain farming situation, we need to estimate the

377 combined contribution of multiple ecosystem services and agricultural inputs (Boreux et

378 al. 2013), as they may be influenced differently by landscape characteristics or have

379 non-additive interactions among them (e.g., Lundin et al. 2013, Martin et al. 2013).

380 Information on the benefit delivered by pollinators to yield quantity and quality in relation

381 to landscape context provides an important baseline for this work.

382 Data deposition: Insect richness, visits per guild, mean yield and quality are reported

383 for each site in appendix 1.

\section{Acknowledgements}

385 We thank H. Dathe, G. Else, R. Fonfria, S. Iserbyt, M. Kuhlmann, G. Le Goff, D. Michez,

386 H. Mouret, A. Müller, S. Patiny, A. Pauly, P. Rasmont, S. Risch, M. Schwarz, R. 
387 Theunert, Waldemar C., and P. Williams for bee identifications to species, V. Zaldo for

388 GIS assistance and V. Gagic for statistical discussions.

\section{References}

390 Andersson GKS, Rundlöf M, Smith HG. 2012. Organic farming improves pollination

391 success in strawberries. PLoS ONE 7(2):e31599 (doi:10.1371/journal.pone.0031599)

392 Angadi SV, Cutforth HW, McConkey BG, Gan Y. 2003. Yield adjustement by canola

393 grown at different plant populations under semiarid conditions. Crop Sciences. 43 :1358-

3941366 (doi:10.2135/cropsci2003.1358).

395 Bartomeus I, Ascher JS, Gibbs J, Danforth BN, Wagner DL, Hedtke SM, Winfree R.

396 2013. Historical changes in northeastern US bee pollinators related to shared ecological

397 traits. Proceedings of the National Academy of Sciences of the United States of

398 America, 110(12), 4656-60. doi:10.1073/pnas.1218503110

399 Bartomeus I, Park MG, Gibbs J, Danforth BN, Lakso AN, Winfree R. 2013. Biodiversity

400 ensures plant-pollinator phenological synchrony against climate change. Ecology letters,

401 16(11), 1331-8. doi:10.1111/ele.12170

402 Bartomeus I, Winfree R. 2013. Pollinator declines: reconciling scales and implications

403 for ecosystem services. F1000Research, 146, 2-4. doi:10.12688/f1000research.2-

404 146.v1

405 Björkman T. 1995. Role of honey bees (Hymenoptera: Apidae) in the pollination 
406 of buckwheat in Eastern North America. Journal of Economic Entomology 88(6): 1739-

$407 \quad 1745$

408 Bommarco R, Kleijn D, Potts SG. 2013. Ecological intensification: harnessing ecosystem

409 services for food security. Trends in ecology \& evolution 28(4) 230-238,

410 doi:10.1016/j.tree.2012.10.012.

411 Bommarco R, Lundin O, Smith HG, Rundlof M. 2011. Drastic historic shifts in bumble-

412 bee community composition in Sweden. Proceedings of the Royal Society B. 279(1727),

$413 \quad 309-315$.

414 doi:10.1098/rspb.2011.0647

415 Bommarco R, Marini L, Vaissière BE. 2012. Insect pollination enhances seed yield,

416 quality, and market value in oilseed rape. Oecologia,169(4), 1025-1032.

417 Bos MM, Veddeler D, Bogdanski AK, Klein AM, Tscharntke T, Steffan-Dewenter I,

418 Tylianakis J M. 2007. Caveats to quantifying ecosystem services: fruit abortion blurs

419 benefits from crop pollination. Ecological Applications, 17(6), 1841-1849.

420 Boreux V, Kushalappa CG, Vaast P, Ghazoul J. 2013. Interactive effects among

421 ecosystem services and management practices on crop production: pollination in coffee

422 agroforestry systems. Proceedings of the National Academy of Sciences of the United

423 States of America, 110(21), 8387-92. doi:10.1073/pnas.1210590110 
424 Breeze TD, Bailey AP, Balcombe KG, SG Potts. 2011. Pollination services in the UK:

425 How important are honeybees? Agriculture, Ecosystems and Environment, 142(3), 137426143.

427 Brittain C, Kremen C, Klein AM. 2012. Biodiversity buffers pollination from changes in 428 environmental conditions. Global Change Biology, 19(2), 540-547.

429 doi:10.1111/gcb.12043

430 Cariveau DP, Williams NM, Benjamin FE, Winfree R. 2013. Response diversity to land 431 use occurs but does not consistently stabilise ecosystem services provided by native 432 pollinators. Ecology letters, 16(7), 903-11. doi:10.1111/ele.12126

433 Carré G, Roche P, Chifflet R, Morison N, Bommarco R, Harrison-Cripps J, Krewenka K, 434 Potts SG,Roberts SPM, Rodet G, Settele J, Steffan-Dewenter I, Szentgyörgyi H, 435 Tscheulin T, Westphal C, Woyciechowski M, Vaissière BE. 2009. Landscape context and 436 habitat type as drivers of bee biodiversity in European annual crops. Agriculture, 437 Ecosystems and Environment, $133: 40-47$.

438 Carvalheiro LG, Kunin WE, Keil P, Aguirre-Gutiérrez J, Ellis WN, Fox R, Groom Q, 439 Hennekens S, Van Landuyt W, Maes D, Van de Meutter F, Michez D, Rasmont P, Ode B, 440 Potts SG, Reemer M, Roberts SPM, Schaminée J, WallisDeVries MF, Biesmeijer JC.

441 2013. Species richness declines and biotic homogenisation have slowed down for NW-

442 European pollinators and plants. Ecology letters, 16(7), 870-8. doi:10.1111/ele.12121 
443 Chacoff NP, Aizen MA, Aschero V. 2008. Proximity to forest edge does not affect crop

444 production despite pollen limitation. Proceedings of the Royal Society B, 275 :907-913

445 (doi: 10.1098/rspb.2007.1547).

446 Chagnon M, Gingras J, Deoliveira D. 1993. Complementary aspects of strawberry

447 pollination by honey and indigenous bees (Hymenoptera). Journal of Economic

448 Entomology, 86, 416-420.

449 Cleasby IR, Nakagawa S. 2011. Neglected biological patterns in the

450 residuals. Behavioral Ecology and Sociobiology, 65(12), 2361-2372.

451 Fahrig L. 2013. Rethinking patch size and isolation effects: the habitat amount

452 hypothesis. Journal of Biogeography, 40(9), 1649-1663. doi:10.1111/jbi.12130

453 Ferguson LB, Watkins CB. 1992. Crop load affects mineral concentrations and incidence

454 of bitter pit in 'Cox's Orange Pippin' apple fruit. Journal of the American Society of

455 Horticultural Sciences, $117: 373-376$.

456 Garibaldi LA, Steffan-Dewenter I, Winfree R, Aizen MA, Bommarco R, Cunningham SA,

457 Kremen C, Carvalheiro LG, Harder LD, Afik O, Bartomeus I, Benjamin F, Boreux V,

458 Cariveau D, Chacoff NP, Dudenhöffer JH, Freitas BM, Ghazoul J, Greenleaf S, Hipólito

459 J, Holzschuh A, Howlett B, Isaacs R, Javorek SK, Kennedy CM, Krewenka KM, Krishnan

460 S, Mandelik Y, Mayfield MM, Motzke I, Munyuli T, Nault BA, Otieno M, Petersen J,

461 Pisanty G, Potts SG, Rader R, Ricketts TH, Rundlöf M, Seymour CL, Schüepp C,

462 Szentgyörgyi H, Taki H, Tscharntke T, Vergara CH, Viana BF, Wanger TC, Westphal C, 
463 Williams N, Klein AM. 2013. Wild pollinators enhance fruit set of crops regardless of

464 honey bee abundance. Science, 339(6127), 1608-11. doi:10.1126/science.1230200

465 Garibaldi LA, Steffan-Dewenter I, Kremen C, Morales JM, Bommarco R, Cunningham 466 SA, Carvalheiro LG, Chacoff NP, Dudenhöffer JH, Greenleaf SS, Holzschuh A, Isaacs R,

467 Krewenka K, Mandelik Y, Mayfield M, Morandin LA, Potts SG, Ricketts TH, Szentgyörgyi

468 H, Viana BF, Westphal C, Winfree R, Klein AM. 2011. Stability of pollination services

469 decreases with isolation from natural areas despite honey bee visits. Ecology

470 Letters, 14(10), 1062-1072.

471 Garratt MPD, Breeze T, Jenner N, Polce C, Biesmeijer JC, Potts SG. 2013. Avoiding a 472 bad apple: insect pollination enhances fruit quality and economic value. Agriculture, 473 Ecosystem and Environment, 184, 4-40.

474 Gomez NV, Miralles DJ. 2011. Factors that modify early and late reproductive phases in 475 oilseed rape (Brassica napus L.): its impact on seed yield and oil content. Industrial 476 Crops and Products, $34: 1277-1285$.

477 Gonzalez MV, Coque M, Herrero M. 1998. Influence of pollination systems on fruit set 478 and fruit quality in kiwifruit (Actinidia deliciosa). Annals of Applied Biology, 132 :349-355.

479 Gotelli NJ, Colwell RK (2001) Quantifying biodiversity: Procedures and pitfalls in the 480 measurement and comparison of species richness. Ecology Letters, 4 :379-391. 
481 Greenleaf SS, Kremen C. 2006. Wild bee species increase tomato production but

482 respond differently to surrounding land use in Northern California. Biological

483 Conservation, 133, 81-87.

484 Greenleaf SS, Williams NM, Winfree R, Kremen C. 2007. Bee foraging ranges and their 485 relationship to body size. Oecologia, 153(3), 589-596.

486 Henry M, Fröchen M, Maillet-Mezeray J, Breyne E, Allier F, Odoux J-F, Decourtye A.

487 2012. Spatial autocorrelation in honeybee foraging activity reveals optimal focus scale 488 for predicting agro-environmental scheme efficiency. Ecological Modeling, 225 :103-114. 489 (doi.org/10.1016/j.ecolmodel.2011.11.015,)

490 Hogendoorn K, Bartholomaeus F, Keller MA. 2010. Chemical and sensory comparison 491 of tomatoes pollinated by bees and by a pollination wand. Journal of Econonic 492 Entomology, 103 :1286-1292.

493 Howpage D, Spooner Hart RN, Vithanage V. 2001. Influence of honey bee (Apis 494 mellifera) on kiwifruit pollination and fruit quality under Australian conditions. New 495 Zeland Journal of Crop Horticultural Sciences, 29 :51-59.

496 Höhn P, Tscharntke T, Tylianakis JM, Steffan-Dewenter I. 2008. Functional group 497 diversity of bee pollinators increases crop yield. Proceedings of the Royal Society of 498 London, Series $B, 275,2283-2291$

499 Isaacs R, Kirk AK. 2010. Pollination services provided to small and large highbush 500 blueberry fields by wild and managed bees. Journal of Applied Ecology, 47, 841-849. 
501 Lundin O, Smith HG, Rundlöf M, Bommarco R. 2013. When ecosystem services

502 interact: crop pollination benefits depend on the level of pest control. Proceedings of the

503 Royal Society B: Biological Sciences, 280, 2012-2243.

504 Kennedy CM, Lonsdorf E, Neel MC, Williams NM, Ricketts TH, Winfree R, Bommarco R,

505 Brittain C, Burley AL, Cariveau D, Carvalheiro LG, Chacoff NP, Cunningham SA,

506 Danforth BN, Dudenhöffer J-H, Elle E, Gaines HR, Garibaldi LA, Gratton C, Holzschuh

507 A, Isaacs R, Javorek SK, Jha S, Klein AM, Krewenka K, Mandelik Y, Mayfield MM,

508 Morandin L, Neame LA, Otieno M, Park M, Potts SG, Rundlöf M, Saez A, Steffan-

509 Dewenter I, Taki H, Viana BF, Westphal C, Wilson JK, Greenleaf SS, Kremen C. 2013. A

510 global quantitative synthesis of local and landscape effects on wild bee pollinators in

511 agroecosystems. Ecology letters, 16(5), 584-99. doi:10.1111/ele.12082

512 Kevan PG, Eisikowitch D. 1990. The effects of insect pollination on canola (Brassica

513 napus L. cv. O.A.C. Triton) seed germination. Euphytica, $45: 39-41$.

514 Klatt BK, Holzschuh A, Westphal C, Clough Y, Smit I, Pawelzik E, Tscharntke T. 2014.

515 Bee pollination improves crop quality, shelf life and commercial value. Proceedings of

516 the Royal Society B: Biological Sciences, 281(1775), 20132440.

517 Klein AM, Vaissiere BE, Cane JH, Steffan-Dewenter I, Cunningham SA, Kremen C,

518 Tscharntke TD. 2007. Importance of pollinators in changing landscapes for world crops.

519 Proceedings of the Royal Society B-Biological Sciences, 303-313. 
520 Klein AM, Steffan-Dewenter I, Tscharntke T. 2003. Pollination of Coffea canephora in

521 relation to local and regional agroforestry management. Journal of Applied Ecology, 40,

$522837-845$.

523 Köpke U, Nemecek T. 2010. Ecological services of faba bean. Field Crops

524 Research, 115(3), 217-233.

525 Le Guen J, Mesquida J, Pierre JS, Morin G, Taséi JN, Carré S. 1993. Efficacité

526 pollinisatrice de différents traitements sur two lignées de féverole de printemps (Vicia

527 faba L. var. equina Steudel), à des niveaux d'autofertilité différents, avec utilisation de

528 diverses espèces de Bombus Latr. (Hymenoptera: Apidae). Apidologie, 24 :129-145.

529 Martin EA, Reineking B, Seo B, Steffan-Dewenter I. 2013. Natural enemy interactions

530 constrain pest control in complex agricultural landscapes. Proceedings of the National

531 Academy of Sciences of the United States of America, 110(14), 5534-9.

532 doi:10.1073/pnas.1215725110

533 Pierre J, Vaissière B, Vallée P, Renard M. 2010. Efficiency of airborne pollen released by

534 honeybee foraging on pollination in oilseed rape: a wind insect-assisted pollination.

535 Apidologie, 41(1), 109-115. (DOI: 10.1051/apido/2009056)

536 Pinheiro J, Bates D, DebRoy S, Sarkar D. 2011. nlme: linear and nonlinear mixed effects

537 models. R package version 3.1-98. R Foundation for Statistical Computing, Vienna. 
538 Potts SG, Biesmeijer JC, Kremen C, Neumann P, Schweiger O, Kunin WE. 2010. Global

539 pollinator declines: trends, impacts and drivers. Trends in Ecology \& Evolution, 25(6),

$540 \quad 345-353$.

541 Rader R, Howlett BG, Cunningham SA, Westcott DA, Newstrom-Lloyd LE, Walker MK,

542 Teulon DAJ, Edwards W. 2009. Alternative pollinator taxa are equally efficient but not as

543 effective as the honeybee in a mass flowering crop. Journal of Applied Ecology, 46(5), :

544 1080-1087 (DOI: 10.1111/j.1365-2664.2009.01700.x).

545 Rader R, Reilly J, Bartomeus I, Winfree R. 2013. Native bees buffer the negative impact

546 of climate warming on honey bee pollination of watermelon crops. Global change

547 biology, 19(10), 3103-10. doi:10.1111/gcb.12264

548 Ricketts TH, Regetz J, Steffan-Dewenter I, Cunningham SA, Kremen C, Bogdanski A,

549 Gemmill-Herren B, Greenleaf SS, Klein AM, Mayfield MM, Morandin LA, Ochieng' A,

550 Potts SG, Viana BF. 2008. Landscape effects on crop pollination services: are there

551 general patterns? Ecology Letters, 11(5), 499-515.

552 Roldan Serrano A, Guerra-Sanz JM. 2006. Quality fruit improvement in sweet pepper 553 culture by bumblebee pollination. Scientia Horticulturae, 110, 160-166.

554 Roselino AC, Santos SB, Hrncir M, Bego LR. 2009. Differences between the quality of

555 strawberries (Fragaria $x$ ananassa) pollinated by the stingless bees Scaptotrigona aff.

556 depilis and Nannotrigona testaceicornis. Genetics and Molecular Research, 8, 539-545. 
557 Sacchi CF, Price PW. 1988. Pollination of the arroyo willow, Salix lasiolepis: role of

558 insects and wind. American Journal of Botany, 1387-1393.

559 Stanley DA, Gunning D, Stout JC. 2013. Pollinators and pollination of oilseed rape crops

560 (Brassica napus L.) in Ireland: ecological and economic incentives for pollinator

561 conservation. Journal of Insect Conservation. doi:10.1007/s10841-013-9599-z

562 Steffan-Dewenter I, Munzenberg U, Burger C, Thies C, Tscharntke TD. 2002. Scale-

563 dependent effects of landscape context on three pollinator guilds. Ecology, 1421-1432.

564 Stivers RK, Swearingin ML. 1980. Soybean yield compensation with different

565 populations and missing plant patterns. Agronomy Journal, 72 :98-102.

566 Vaissière BE, Freitas BM, Gemill-Herren B. 2011. Protocol to detect and assess

567 pollination deficits in crops: a handbook for its use. FAO, Rome, Italy. 81 pp.

568 Westphal C, Bommarco R, Carré G, Lamborn E, Morison N, Petanidou T, Potts SG,

569 Roberts SPM, Szentgyörgyi H, Tscheulin T, Vaissière BE, Woyciechowski M, Biesmeijer

570 JC, Kunin WE, Settele J, Steffan-Dewenter I. 2008. Measuring bee diversity in different

571 european habitats and biogeographical regions. Ecological Monographs, 78(4), 653-

572 671. doi:10.1890/07-1292.1

573 Westphal C, Steffan-Dewenter I, Tscharntke T. 2003. Mass flowering crops enhance

574 pollinator densities at a landscape scale. Ecology Letters, 6(11), 961-965.

doi:10.1046/j.1461-0248.2003.00523.x 
576 Williams NM, Crone EE, Roulston TH, Minckley RL, Packer L, Potts SG. 2010.

577 Ecological and life-history traits predict bee species responses to environmental

578 disturbances. Biological Conservation, 143, 2280-2291.

579 Williams IH, Martin AP, White RP. 1986. The pollination requirements of oilseed rape

580 (Brassica napus L.). Journal of Agricultural Science, 106 :27-30.

581 Winfree R, Bartomeus I, Cariveau DP. 2011. Native pollinators in anthropogenic

582 habitats. Annual Review of Ecology Evolution and Systematics, 42, 1-22.

583 doi:10.1146/annurev-ecolsys-102710-145042

584 Winfree R, Williams NM, Dushoff J, Kremen C. 2007. Native bees provide insurance

585 against ongoing honey bee losses. Ecology letters, 10(11), 1105-13.

586 doi:10.1111/j.1461-0248.2007.01110.x

587 Wragg PD, Johnson SD. 2011. Transition from wind pollination to insect pollination in

588 sedges: experimental evidence and functional traits. New Phytologist, 191(4), 1128-

5891140.

590 Zebrowska, J. 1998. Influence of pollination modes on yield components in strawberry

591 (Fragaria x ananassa Duch). Plant Breeding, 117 :255-260 (DOI: 10.1111/j.1439-

592 0523.1998.tb01935.x). 


\section{Table 1 (on next page)}

Contribution of insect pollinators to crop yield and quality varies with agricultural intensification Characteristics of the four study systems.

Contribution of insect pollinators to crop yield and quality varies with agricultural intensification For each crop, the variety used, the distance between fields, field size and mean pollinator richness is shown. 


\begin{tabular}{|c|c|c|c|c|c|}
\hline & Variety & $\begin{array}{rr}\text { Distance } & \text { Field } \\
\text { between } & \text { sizes } \\
\text { sites } & \text { (range in } \\
\text { (range in } & \text { ha) } \\
\text { km) } & \end{array}$ & $\begin{array}{r}\text { Mean } \\
\text { species } \\
\text { richness of } \\
\text { pollinators }\end{array}$ & $\begin{array}{r}\text { Percentage } \\
\text { agriculture } \\
\text { in } 500 \mathrm{~m} \\
\text { buffer } \\
\text { (range) }\end{array}$ & $\begin{array}{r}\text { Percentag } \\
\text { e } \\
\text { agriculture } \\
\text { in } 1000 \mathrm{~m} \\
\text { buffer } \\
\text { (range) }\end{array}$ \\
\hline $\begin{array}{l}\text { Oil seed } \\
\text { rape }\end{array}$ & Stratos & $3-71.0-40.4$ & 11.3 & $14-50$ & 111 \\
\hline Field bean & Clipper & $3-185.0-47.0$ & 3.1 & $34-99$ & $35-$ \\
\hline Strawberry & $\begin{array}{l}\text { Honeoye, } \\
\text { Korona, } \\
\text { Darselect, } \\
\text { Symphoni } \\
\text { e }\end{array}$ & $3-260.3-1.3$ & 12.9 & $51-99$ & $48-$ \\
\hline Buckwheat & Kora & $4-70.3-4.0$ & 11.4 & $29-82$ & $41-7$ \\
\hline
\end{tabular}




\section{Table 2 (on next page)}

Effects of land use complexity on total visitation, honeybee visitation (field beans were excluded from the honeybee model), and non honeybee visitation.

Visitation is scaled within each crop. Both models include block nested in site as random factors. Agriculture is the proportion of arable land in the surrounding landscape of each field. The slopes and standard errors (SE) of each crop are shown. 


\begin{tabular}{|c|c|c|c|}
\hline Total visitation & F-value & D.f. & P-value \\
\hline Crop & 3.13 & 3 & 0.04 \\
\hline Agriculture $1 \mathrm{~km}$ & 0.05 & 1 & 0.81 \\
\hline Agriculture ${ }^{\star}$ crop & 3.08 & 3 & 0.04 \\
\hline Residuals & & 32 & \\
\hline Slopes & Estimate & SE & \\
\hline Field bean & 0.52 & 2.19 & \\
\hline Buckwheat & 1.78 & 4.86 & \\
\hline Oilseed rape & -4.78 & 4.99 & \\
\hline Strawberry & -2.83 & 5.57 & \\
\hline \multicolumn{4}{|l|}{$\begin{array}{l}\text { Honeybee } \\
\text { visitation }\end{array}$} \\
\hline Crop & 2.05 & 2 & 0.15 \\
\hline Agriculture $1 \mathrm{~km}$ & 2.63 & 1 & 0.12 \\
\hline Agriculture*crop & 3.87 & 2 & 0.03 \\
\hline Residuals & & 32 & \\
\hline Slopes & Estimate & SE & \\
\hline Buckwheat & 1.72 & 1.41 & \\
\hline Oilseed rape & -4.59 & 3.56 & \\
\hline Strawberry & -3.38 & 4.21 & \\
\hline \multicolumn{4}{|l|}{$\begin{array}{l}\text { Non-honeybee } \\
\text { visitation }\end{array}$} \\
\hline Crop & 0.56 & 3 & 0.64 \\
\hline Agriculture $1 \mathrm{~km}$ & 0.92 & 1 & 0.35 \\
\hline Agriculture*crop & 3.34 & 3 & 0.03 \\
\hline Residuals & & 32 & \\
\hline Slopes & Estimate & SE & \\
\hline Field bean & 2.50 & 0.72 & \\
\hline Buckwheat & 0.06 & 1.59 & \\
\hline Oilseed rape & -0.19 & 1.64 & \\
\hline Strawberry & 0.55 & 1.81 & \\
\hline
\end{tabular}




\section{Table 3 (on next page)}

Effects of open pollination vs pollinator exclusion treatments, visitation and landscape context on yield

Data for four entomophilous crops grown over 10 fields in Europe (buckwheat, field bean, spring oilseed rape and strawberry). Yield and visitation are scaled within each crop. Block, nested in site, nested in crop are included as a random factor. Agriculture is the proportion of arable land in the surrounding landscape of each field. The slopes and standard errors (SE) of each treatment level are shown. 


\begin{tabular}{lrrr} 
& F-value & Df & P-value \\
\hline Pollination treatment & 51.51 & 226 & $<\mathbf{0 . 0 0 1}$ \\
Pollinator richness & 0.37 & 27 & 0.547 \\
Total number of visits & 6.65 & 27 & $\mathbf{0 . 0 1 5}$ \\
Agriculture 1 km radius & 0.01 & 27 & 0.946 \\
Treatment*Pollinator & 0.01 & 226 & 0.973 \\
richness & & & \\
Treatment*Total number & 0.15 & 226 & 0.701 \\
of visits & & & \\
Treatment*Agriculture & 9.67 & 226 & $\mathbf{0 . 0 0 2}$ \\
& Estimate & SE & \\
Slope Visits Net & 0.33 & 0.13 & \\
Slope Visits Open & 0.28 & 0.21 & \\
Slope Agriculture Net & 0.65 & 0.54 & \\
Slope Agriculture Open & -0.53 & 0.91 & \\
\hline
\end{tabular}




\section{Figure 1}

\section{Experimental design.}

Schema of the experimental design replicated in each of the 10 fields per crop showing the four blocks with two treatments each block and the $150 \mathrm{~m}$ transect surrounding the blocks.
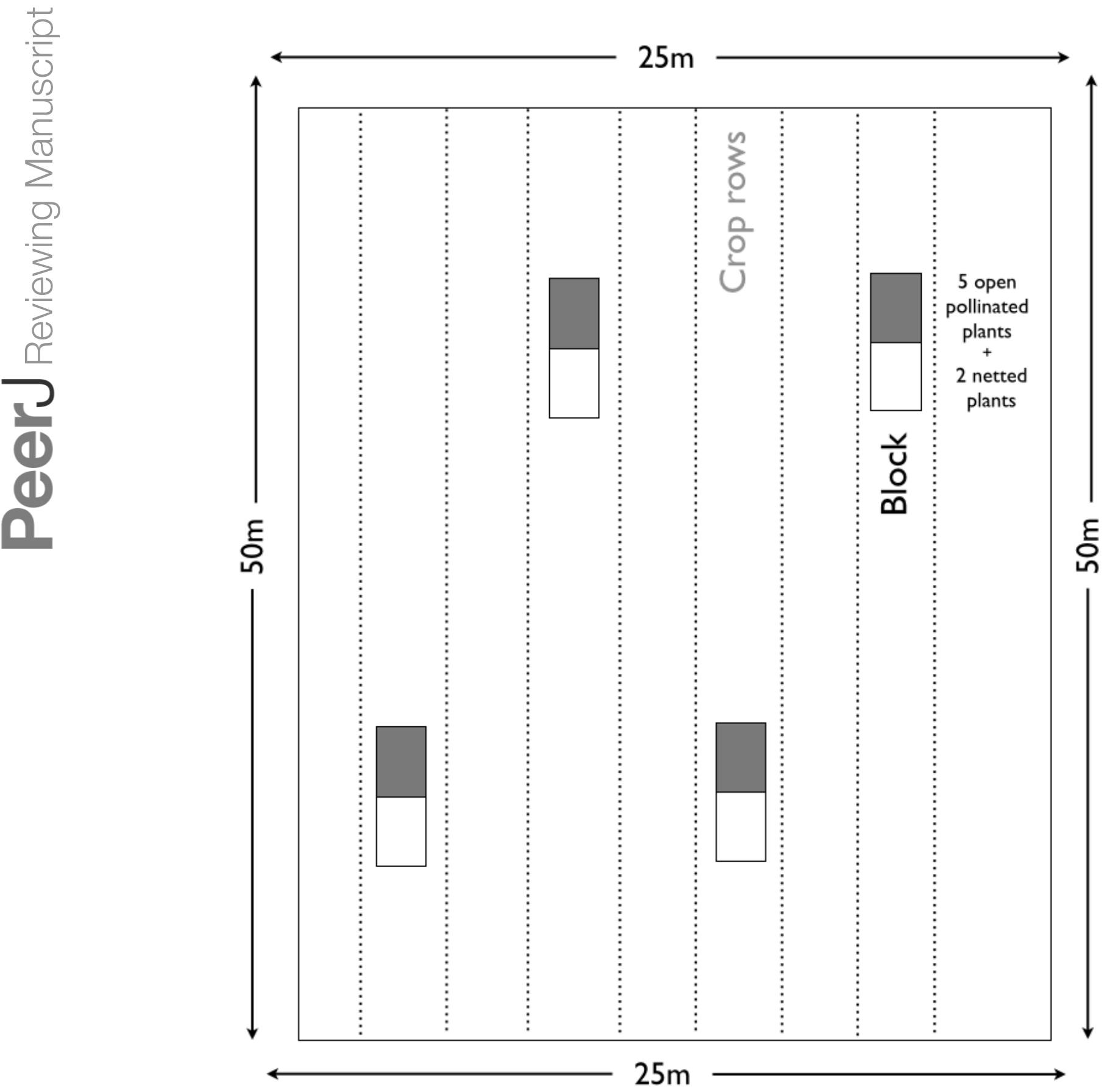


\section{Figure 2}

Total number of visits recorded per pollinator guild in each crop.

All crops received the same sampling effort (i.e., four 30 minutes visits to $150 \mathrm{~m}$ transects). Note the strong dominance of honeybees in most crops.

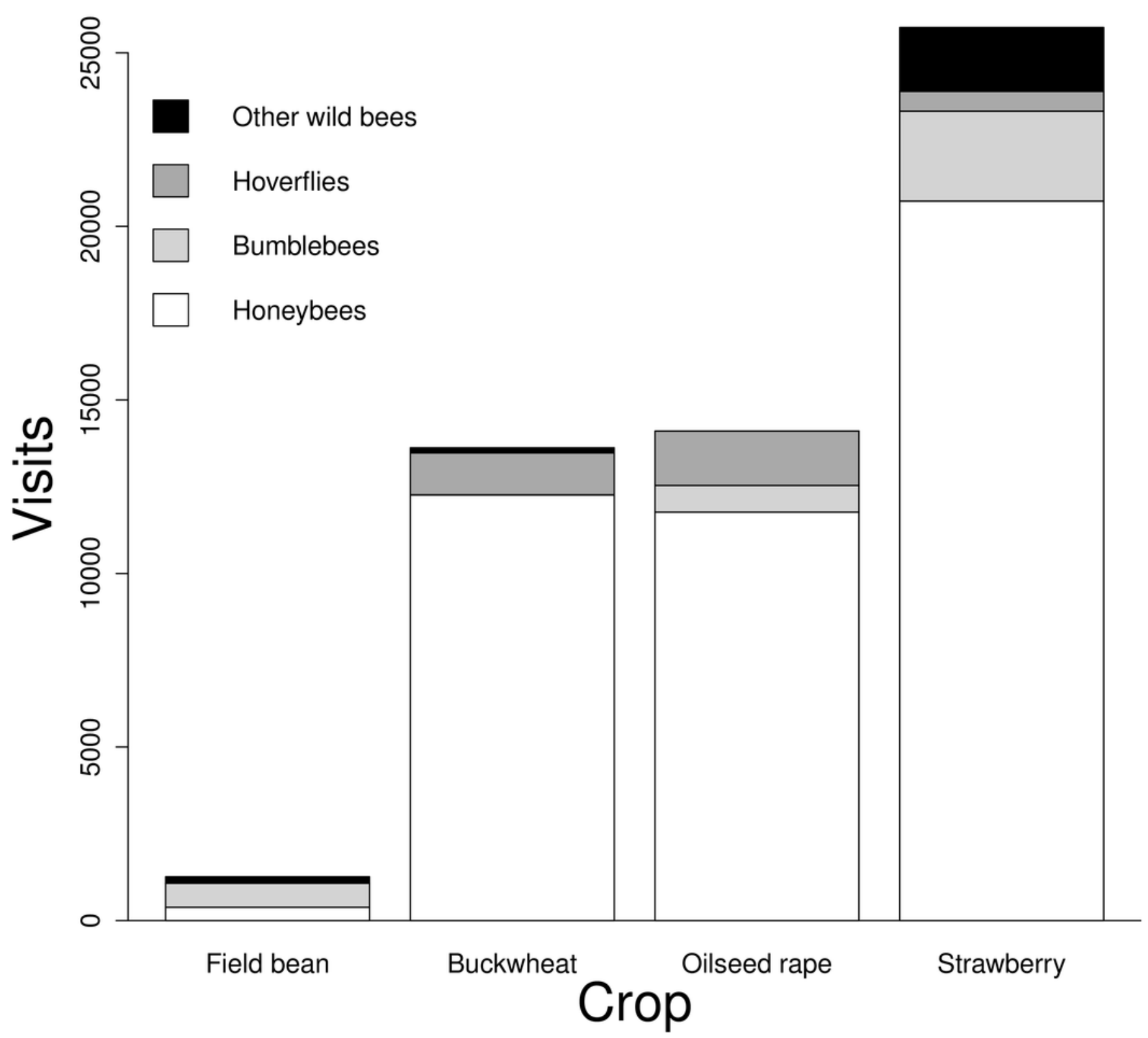




\section{Figure 3}

Contribution of insect pollinators to crop yield and quality varies with agricultural intensification Landscape effects on pollinators

Relationship of A) Pollinator richness per field and B) Total number of visits per field with landscape complexity (\% agriculture) at the appropriate radii. Each crop individual trend is plotted in a different color. Total visits are scaled within each crop.
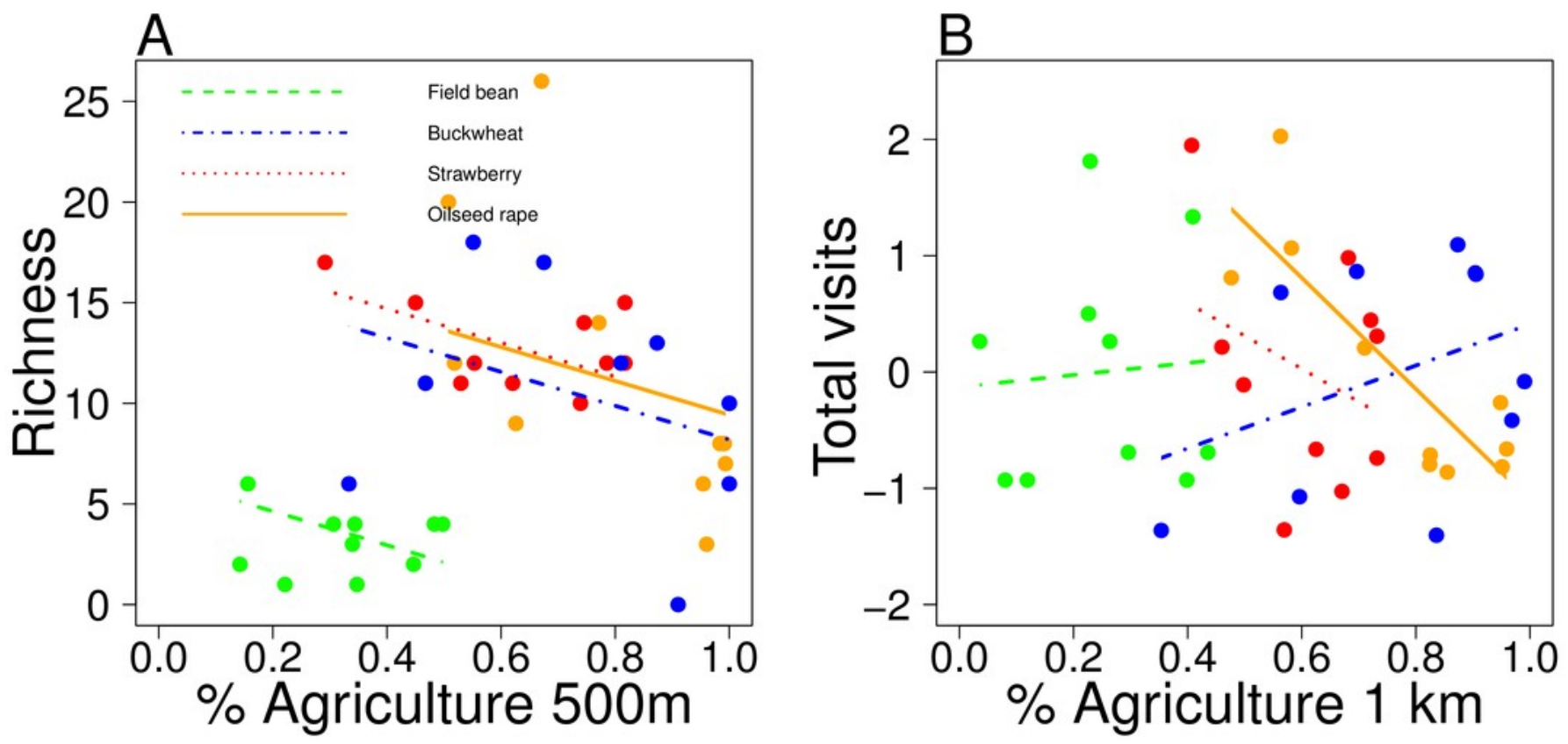


\section{Figure 4}

Pollinator contribution to yield

Overall yield per plant $(A, C, E, G)$ and quality $(B, D, F, H)$ with pollinator exclusion (Net) and open pollination (Open) for each crop. Black dots are the mean values reported in the text, and the boxplots reflects the distribution of the data. Yield is measured in seed weight per plant (g) for all crops except strawberry, which was measured as fruit weight per plant (g). Commercial Grades of 1 and 2 are marketable, while grade 3 is considered non marketable. 

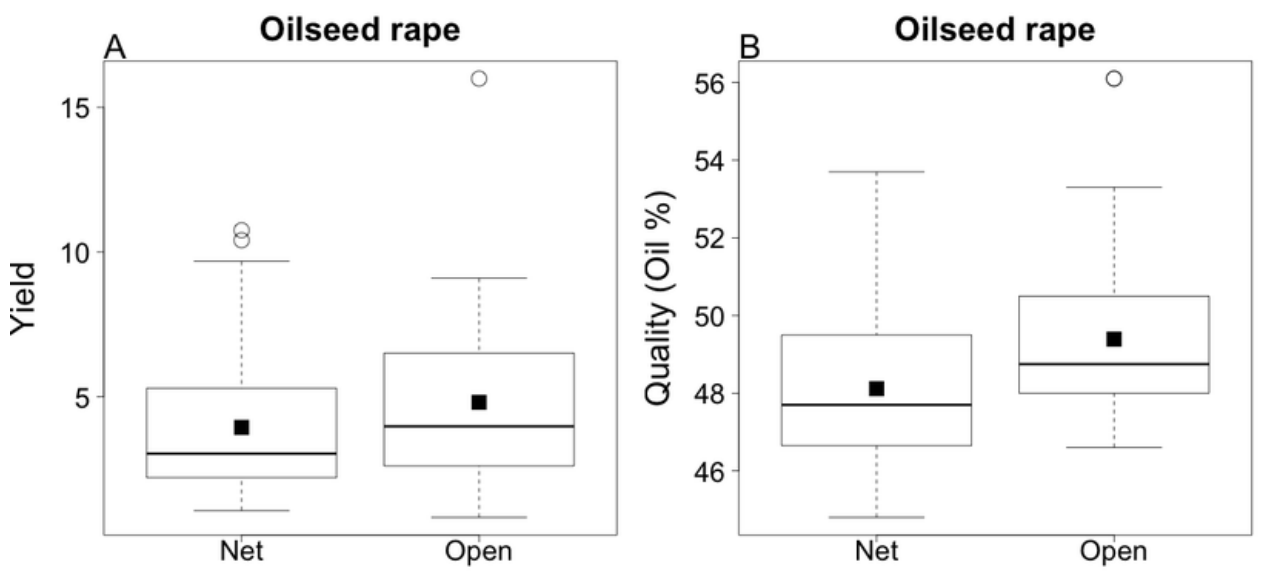

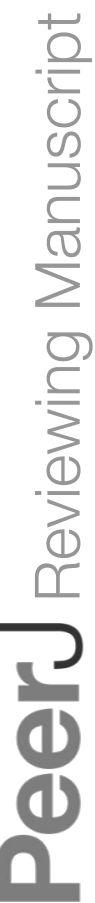
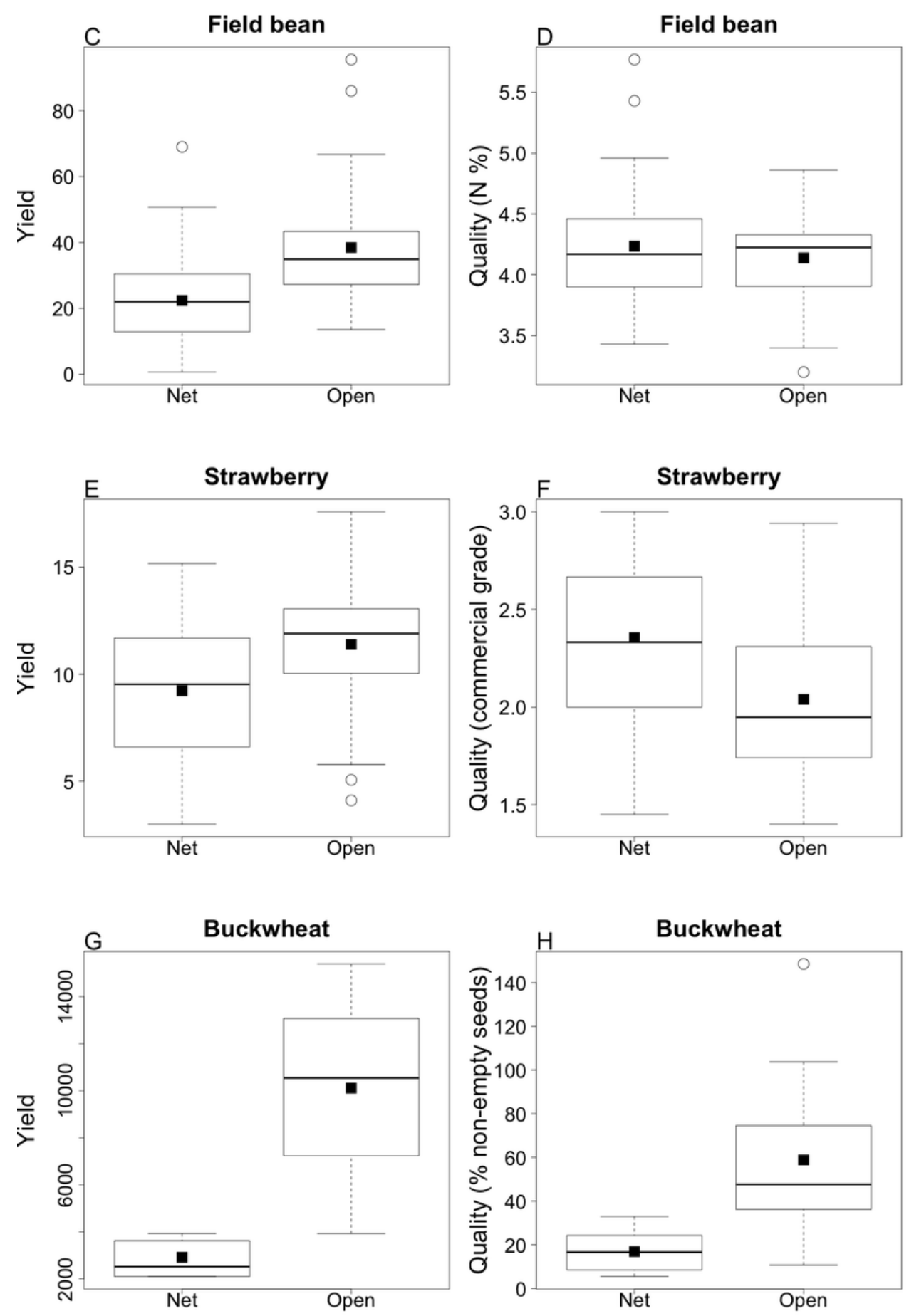

PeerJ reviewing PDF | (v2013:12:1276:1:0:NEW 6 Mar 2014) 


\section{Figure 5}

Visitation and landscape effects on yield

Interaction plots showing the relationships of A) Yield per plant and total visitation and B)

Yield and landscape complexity for pollinator exclusion (open circles, doted line) and open pollination (black circles, solid line). Total visitation and yield are scaled to a mean of zero within each crop.
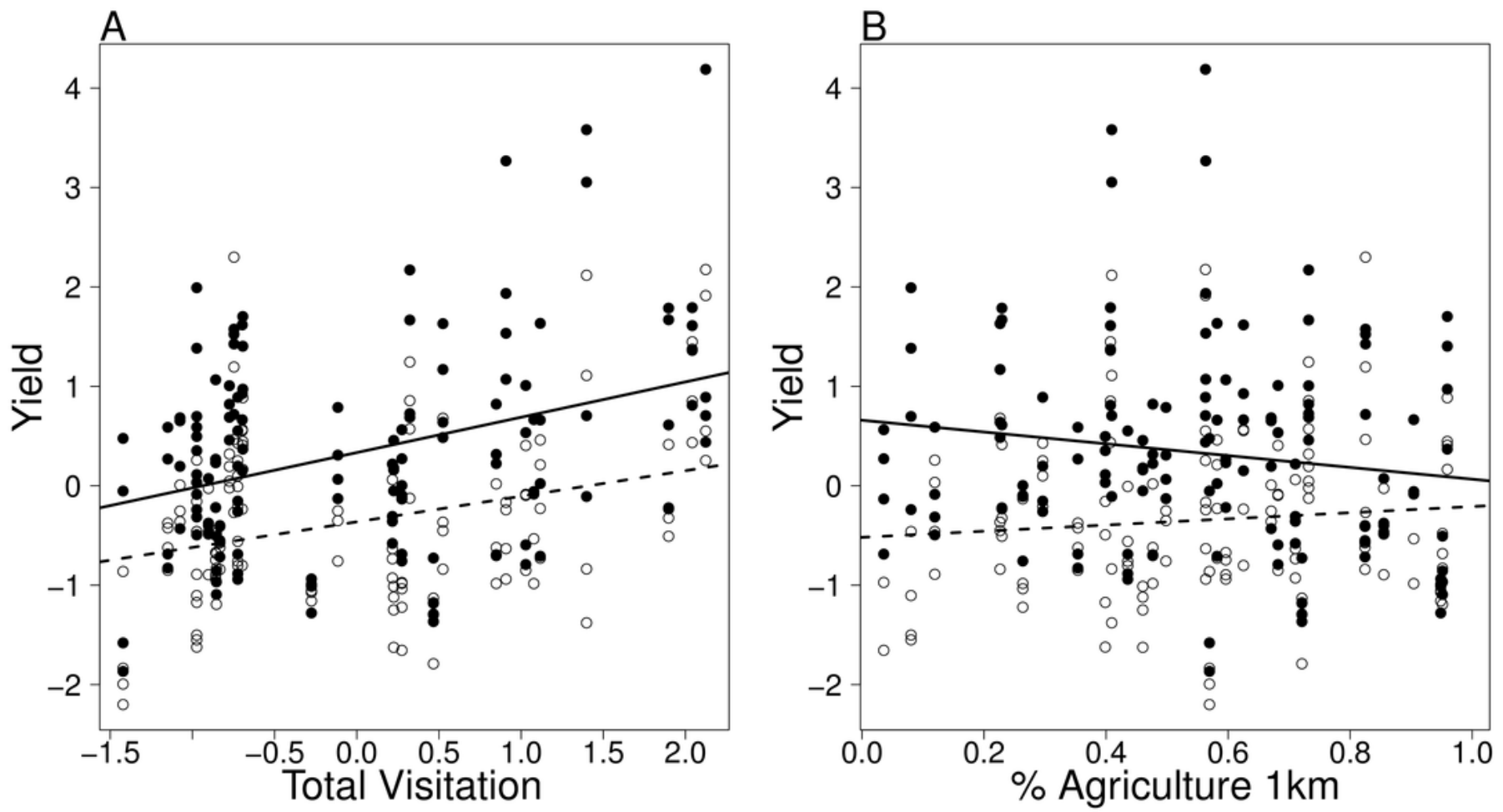